\title{
Edukasi Pencegahan Covid-19 Berbasis Video bagi Remaja di Rumah Yatim Bina Anak Sholeh
}

\author{
Khodijah $^{1}$, Ita Nur Itsna ${ }^{2}$, Anisa Oktiawati ${ }^{3}$ \\ ${ }^{1}$ Program Studi S1 Keperawatan STIKes Bhakti Mandala Husada Slawi \\ ${ }^{2,3}$ Program Studi D3 Keperawatan STIKes Bhakti Mandala Husada Slawi \\ Email: kaisya449@gmail.com
}

Submitted : 29/10/2020

Accepted: $13 / 11 / 2020$

Published: 11/01/2021

\begin{abstract}
Coronavirus is a group of viruses that can cause disease in animals or humans. Several types of coronavirus are known to cause respiratory infections in humans ranging from coughs and colds to more serious ones such as Middle East Respiratory Syndrome (MERS) and Severe Acute Respiratory Syndrome (SARS). One way that can be done to help the government break the increasing chain of COVID-19 transmission is to get used to the implementation of Clean and Healthy Behavior (PHBS) in all groups, both parents and children. The results of interviews with adolescents at the Bina Anak Sholeh Orphanage showed that they had not received clear information on COVID-19 prevention, so they wanted information about COVID-19 directly. Objective: Increase knowledge of adolescents about the prevention of COVID-19 based on video for teenagers at the Sholeh orphanage. Method: Implementation of community service by providing education to adolescents with COVID-19 prevention videos was held on Thursday, October 8, 2020. Results: The results of the evaluation of the activities that have been carried out show that youth are very enthusiastic about participating in extension activities from beginning to end. The results of the questions and answers carried out by the moderator after the delivery of counseling materials confirmed that most participants had understood the COVID-19 material and that they could re-practice proper hand washing as a form of prevention from COVID-19. Conclusion: This service is expected to be able to increase knowledge about the prevention of COVID - 19 and be able to implement clean and healthy living habits in everyday life.
\end{abstract}

Keywords: covid-19, teenager, video

\begin{abstract}
Abstrak
Coronavirus merupakan suatu kelompok virus yang bisa menyebabkan penyakit pada hewan atau manusia. Beberapa jenis coronavirus diketahui dapat menyebabkan infeksi saluran nafas pada manusia mulai dari batuk dan pilek hingga yang lebih serius seperti Middle East Respiratory Syndrome (MERS) dan Severe Acute Respiratory Syndrome (SARS). Salah satu cara yang dapat dilakukan untuk membantu pemerintah memutus rantai penularan COVID-19 yaitu dengan membiasakan penerapan Perilaku Hidup Bersih dan Sehat (PHBS) pada seluruh kelompok baik orang tua maupun anak-anak. Hasil wawancara dengan remaja yang berada di Rumah Yatim Bina Anak Sholeh bahwa mereka belum mendapatkan informasi pencegahan COVID-19 yang jelas, sehingga menginginkan informasi tentang COVID-19 secara langsung. Tujuan: Meningkatkan pengetahuan remaja tentang pencegahan COVID-19Berbasis Video Bagi Remaja Di Rumah Yatim Bina Anak Sholeh. Metode: Pelaksanaan pengabdian masyarakat dengan memberikan edukasi pada remaja dengan video pencegahan COVID-19 dilaksanakan pada hari kamis, Tanggal 8 Oktober 2020.Hasil: Hasil evaluasi dari kegiatan yang sudah dilakukan terlihat bahwa remaja sangat antusias mengikuti kegiatan penyuluhan dari awal sampai akhir. Hasil tanya jawab yang dilakukan moderator setelah penyampaian materi penyuluhan dapat dipastikan bahwa sebagian besar peserta sudah memahami materi COVID-19 dan mereka bisa mempraktekan kembali cara cuci tangan yang benar sebagai bentuk pencegahan dari COVID-19. Kesimpulan:Pengabdian ini diharapkan mampu meningkatkan pengetahuan tentang pencegahan COVID - 19 dan dapat menerapkan perilaku hidup bersih dan sehat dalam kehidupan sehari-hari.
\end{abstract}

Kata Kunci : covid-19, remaja, video 


\section{PENDAHULUAN}

Coronavirusmerupakan

suatu

kelompok virus yang bisa menyebabkan penyakit pada hewan atau manusia. Beberapa jenis coronavirus diketahui dapat menyebabkan infeksi saluran nafas pada manusia mulai dari batuk dan pilek hingga yang lebih serius seperti Middle East Respiratory Syndrome (MERS) dan Severe Acute Respiratory Syndrome (SARS) (Guan, dkk 2020). Coronavirus jenis baru yang ditemukan menyebabkan penyakit COVID-19 (World Health Organization, 2020).Hingga saat ini laju penyebaran penyakit infeksi Virus COVID-19semakin cepat meningkat melalui droplet berupa tetesan air liur atau keluar dari hidung ketika orang yang terinfeksi batuk atau bersin.

Upaya penanggulangan penyebaran COVID-19 yang sangat cepat ini sudah dilakukan pemerintah dalam berbagai aspek kehidupan. Di bidang pendidikan, pemerintah menerapkan pelaksanaan program belajar di rumah (Kemendikbud, 2020). Hal ini bisa melalui berbagai media berbasis internet maupun melalui media yang tidak berbasis internet (Darmalaksana, dkk 2020). Di bidang sosial masyarakat, pemerintah dengan antusias mencanangkan berbagai konsep mitigasi komunitas :seperti pengurangan frekuensi pertemuan besar, pembatasan jarak antar orang di fasilitas umum, hingga penerapan konsep aktivitas yang lebih baik dilaksanakan di rumah. Di bidang kesehatan, pemerintah telah memberikan edukasi kepada masyarakat terkait pentingnya hidup bersih dan sehat, perlunya mengenakan masker saat di luar rumah, pelaksanaan karantina mandiri untuk orang-orang yang memiliki risiko tinggi, serta berbagai pedoman yang bertujuan untuk mencegah penularan COVID-19 (Telaumbanua, 2020).

Pemerintah telah melakukan berbagai upaya dalam menanggulangi penyebaran COVID-19, namun penambahan kasus positif COVID-19 di Indonesia semakin terus bertambah. Hal ini dapat disebabkan karena kurangnya pengetahuan terhadap pandemi yang berdampakpada kurangnya kesadaran masyarakat sehingga penanganan (pencegahan bagi yang tidak terinfeksi dan atau pengobatan terhadap yang terkena wabah) kurang terintegrasi-interkoneksi dalam sistem pemerintahan di negara kita. Dari pusat sampai bagian paling bawah, yaitu desa (kampung). Hal ini sangat berbahaya karena penyebaran COVID-19 sangat rentan tertular melalui mata, hidung, dan mulut (WHO, 2020).

Upaya mengatasi masalah ini diperlukan proses pemahaman dan adaptasi lebih lanjut untuk diterapkan pada semua kalangan masyarakat, khususnya orang tua dan anak-anak. Upaya pencegahan untuk meminimalisir resiko tertularnya infeksi COVID-19 ini dilakukan oleh pemerintah dengan meminta setiap sekolah untuk melakukan pembelajaran dari rumah dengan memberikan edukasi yang tepat untuk mencegah penularan pada anak. Salah satu cara yang dapat dilakukan untuk membantu pemerintah memutus rantai penularan COVID-19 yang semakin meningkat yaitu dengan membiasakan penerapan Perilaku Hidup Bersih dan Sehat (PHBS) pada seluruh kelompok baik orang tua maupun anak-anak.

Kelompok usia anak perlu mendapatkan pendampingan secara langsung di rumah tentang praktek langsung ketrampilan pencegahan diri dari penularan COVID-19. Anak-anak membutuhkan role model yang mendampingi upaya perlindungan diri dari penularan COVID19 meliputi cara mencuci tangan dengan sabun dengan waktu minimal 20 detik, menghindari memegang area yang beriko tempat masuknya penularan COVID seperti mukosa mata hidung atau mulut. Anak-anak juga memerlukan pembiasaan perilaku seperti 
segera berganti pakaian saat keluar dari rumah. Pembiasaan lainnya yang perlu diberikan contoh langsung diantaranya menutup mulut ketika batuk atau bersin (Rohita, 2020).

Pemilihan media pembelajaran yang tepat dapat membantu dalam pemberian edukasi pada anak khususnya pada usia remaja dimana anak mengalami perkembangan yang sangat pesat dalam hal pemikiran, pengetahuan serta pemahaman pad materi yang diberikan. Menurut Sanjaya (2012), media pembelajaran merupakan segala sesuatu yang dapat digunakan untuk menyalurkan pesan dari pengirim ke penerima sehingga dapat merangsang pikiran, perasaaan, perhatian dan minat serta perhatian siswa sedemikian rupa sehingga proses belajar terjadi, untuk menambah pengetahuan, mengubah sikap serta menanamkan keterampilan pada setiap orang yangmemanfaatkannya.

Kehadiran media pembelajaran diharapkan mampu menghilangkan kejaenuhan siswa dalam belajar, sehingga siswa lebih fokus dalam pembelajaran. Media pembelajaran mempunyai peran yang penting dalam proses belajar mengajar, karena dapat membuatsuasana belajar menjadi lebih hidup dan bermakna (Sudjana, 2013).Salah satu media pembelajaran yang digunakan adalah berupa video. Menurut Hardianti dan Asri (2017), penggunaan media video dapat merangsang pengetahuan siswa, melatih berpikir logis, analistik, lebih kreatif, efektif, mempertajam daya imajinasi siswa dan menyenangkan. Dasar pertimbangan memilih video sebagai media pembelajaran agar dapat melatih remaja berpikir logis, konkrit, lebih realistis, dan remaja lebih terfokus pada media pembelajaran yang baru seperti media video ini, kemudian proses belajar lebih aktif, kreatif, dan berkesan. Dengan pemanfaatan media video ini diharapkan mampu meningkatkan kemampuan remaja, utamanya dalam keterampilan dalam melakukan tindakan pencegahan COVID-19.

Sebagai salah satu civitas akademika yang memiliki tugas Tri Dharma Perguruan Tinggi terpanggil untuk turut berkontribusi bersama dalam menghadapi COVID-19 melalui upaya edukasi kepada remaja khususnya di Rumah Yatim Bina Anak Sholeh Slawi.Rumah Yatim Bina Anak Sholeh berada di Jalan Gajah Mada No.77 RT 04/RW IVKalisapu Slawi. Berdasarkan hasil wawancara dengan pengurus Rumah Yatim Bina Anak Sholeh,tim pengabdian mendapatkan informasi bahwa jumlah remaja yang yang berada di sana ada 9 remaja putra dan 16 remaja putri. Salah satu remaja mengatakan belum pernah mendapatkan informasi tentang COVID-19.

\section{TARGET DAN LUARAN}

Sasaran pengabdian masyarakat ini adalah remaja yang berada di Rumah Yatim Bina Anak Sholeh. Luaran yang diharapkan dalam pengabdian masyarakat yang bertemakan"Edukasi Pencegahan COVID19 berbasis video bagi ramaja di Rumah Yatim Bina Anak Sholeh" adalah Meningkatkan pengetahuan remaja di Rumah Yatim Bina Anak Sholeh tentang COVID-19, Memberikan pengetahuan COVID-19 melalui pemutaran video pencegahan COVID-19, Memberikan pengetahuan tentang contoh Pencegahan COVID-19 dengan teknik cuci tangan yang benar.

\section{METODE PELAKSANAAN}

Pelaksanaan pengabdian masyarakat berjudul Penyuluhan Kesehatan Life Skill Remaja Masa Pandemi Covid 19Di Rumah Yatim Bina Anak Sholeh dilaksanakan pada hari Kamis, Tanggal 8 Oktober 2020 Pukul $09.00 \mathrm{~s} / \mathrm{d} 13.00$ WIB. Metode yang digunakan adalah ceramah dan diskusi dengan remaja tentang pencegahan COVID 19. Umpan balik dari peserta di lakukan dengan tanya jawab setelah materi yang 
disampaikan selesai. Kegiatan pengabdian masyarakat inidihadiri oleh 9 remaja putra dan 16 remaja putri yang ada di Rumah Yatim Bina Anak Sholeh.

\section{HASIL DAN PEMBAHASAN}

Hasil dari pengabdian masyarakat ini menunjukkan adanya kepuasan dari remaja di Rumah Yatim Bina Anak Sholeh.

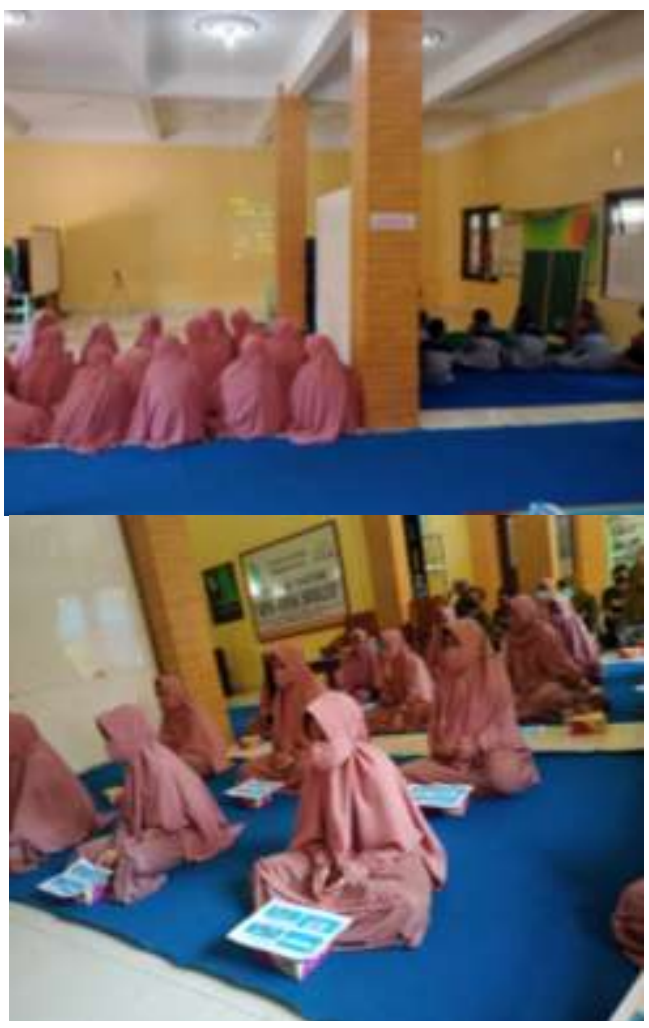

Gambar 1. Peserta Penyuluhan Kesehatan

Pelaksanaan pengabdian masyarakat ini dilakukan pada bulan Oktober 2020, dengan beberapa tahapan pelaksanaan. Yaitu, melakukan penyuluhan tentang pencegahan COVID-19pada remaja, kemudian memberikan contoh cuci tangan yang benar sebagai bentuk pencegahan COVID-19.

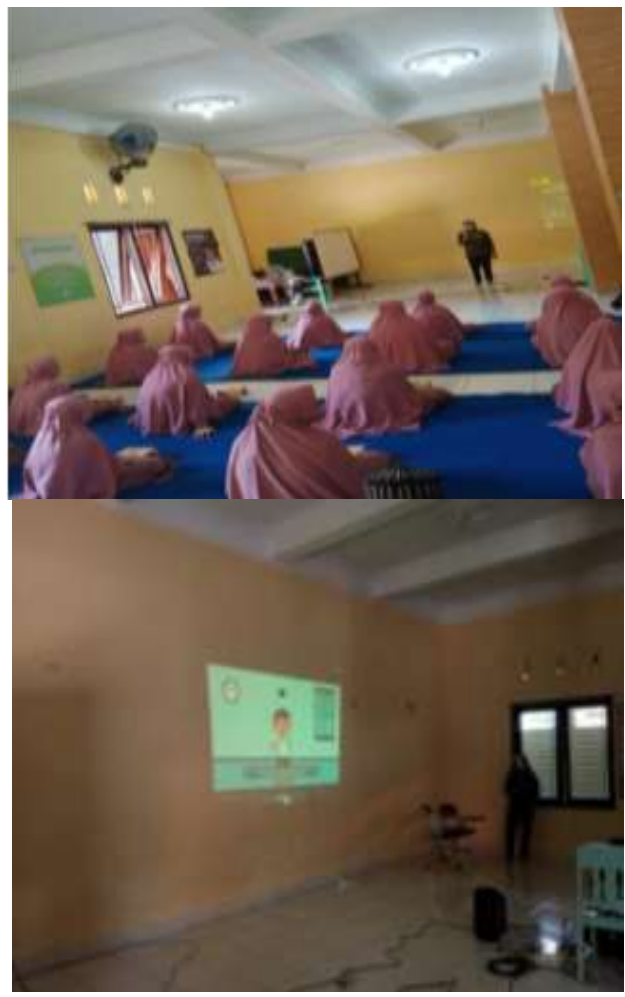

Gambar 2. Ibu Anisa Oktiawati Melakukan Penyuluhan tentang COVID-19 berbasis video

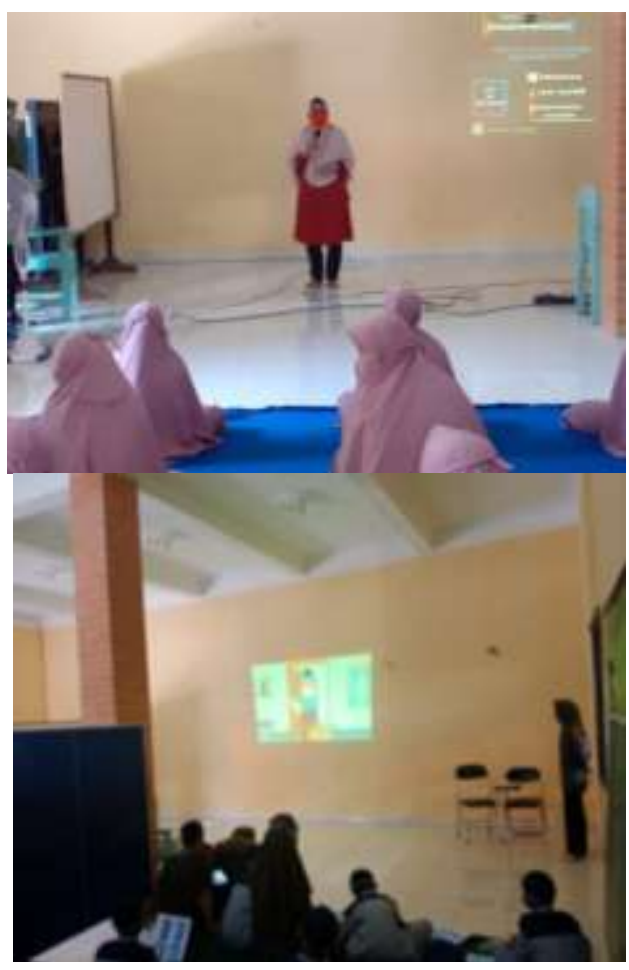

Gambar 3. Ibu Ita Nur Itsna Melakukan Penyuluhan tentang COVID-19 berbasis video 


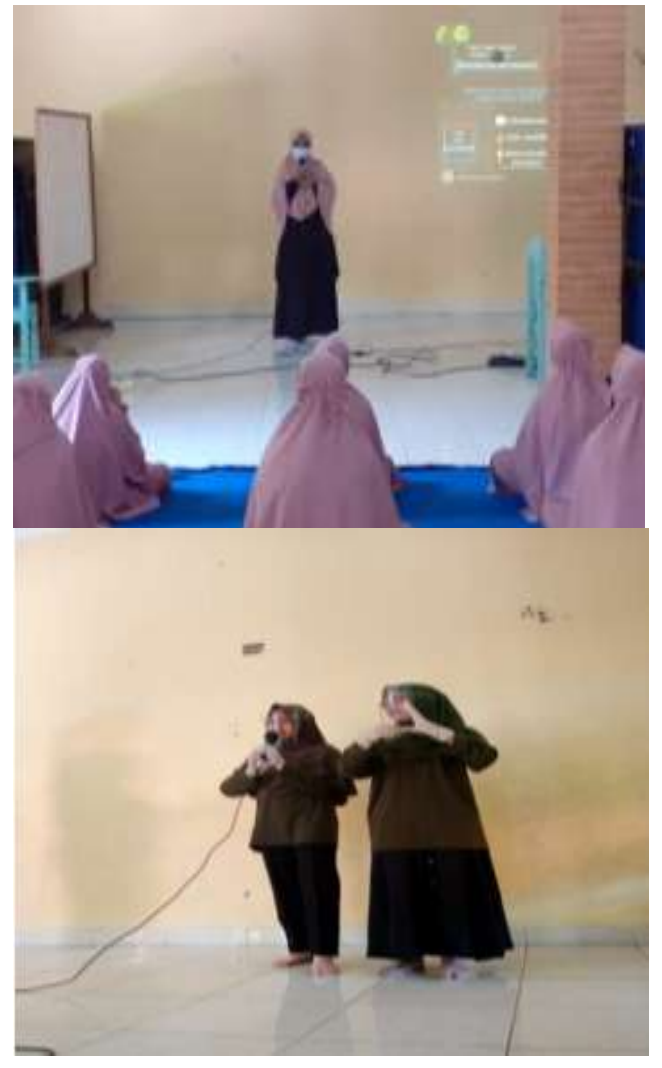

Gambar 4. Ibu Khodijah Memberikan contoh cuci tangan yang benar

Hasil evaluasi dari kegiatan yang sudah dilakukan terlihat bahwa remaja sangat antusias mengikuti kegiatan penyuluhan dari awal sampai akhir. Hasil tanya jawab yang dilakukan moderator setelah penyampaian materi penyuluhan dapat dipastikan bahwa sebagian besar peserta sudah memahami materi COVID-19 dan mereka bisa mempraktekan kembali cara cuci tangan yang benar sebagai bentuk pencegahan dari COVID-19.

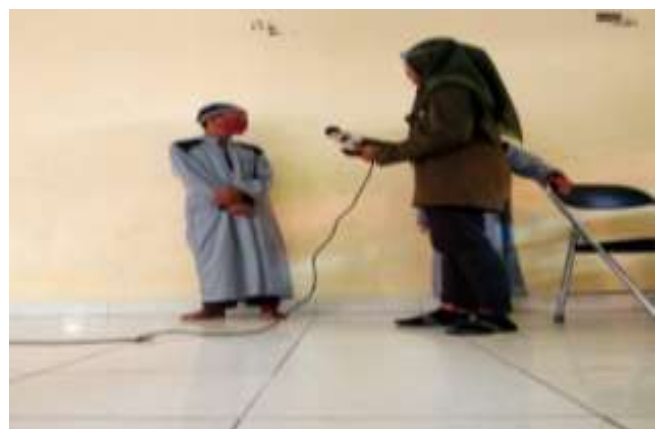

Gambar 5. Peserta sedang menjelaskan tentang COVID-19

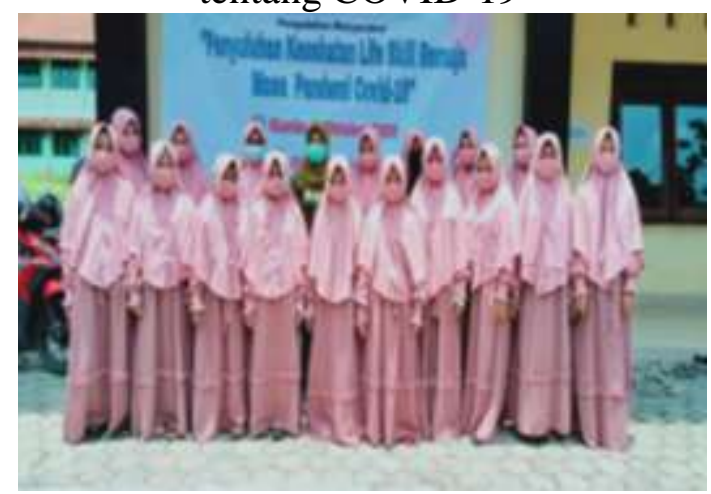

Gambar 6. Foto Bersama dengan Peserta Pengabdian Masyarakat

Coronavirus Disease-19 (Covid-19) merupakan penyakit yang disebabkan oleh virus Severe Acute Respiratory Syndrome Coronavirus-2 (SARS-CoV-2) (WHO, 2020). Penyakit ini merupakan penyakit baru sehingga perlu adanya tindakan pencegahan Covid-19, salah satunya tindakan proteksi dasar. Tindakan proteksi dasar yang direkomendasikan oleh WHO diantaranya mencuci tangan menggunakan sabun dan air atau dengan alkohol, menjaga jarak dengan seseorang yang memiliki gejala batuk maupun bersin, melakukan etika batuk atau bersin dengan benar (WHO, 2020). Tindakan ini dilakukan untuk merubah perilaku individu dalam rangka pencegahan suatu penyakit. Perilaku kesehatan merupakan suatu respon dari organisme terhadap obyek atau stimulus yang berhubungan dengan sakit dan penyakit, system pelayanan kesehatan, makanan dan minuman serta lingkungan. Perilaku pemeliharaan ini meliputi 3 aspek diantaranya perilaku pencegahan penyakit, penyembuhan apabila sakit dan pemulihan kesehatan apabila telah sembuh dari sakit (Notoatmodjo, 2010).

Perubahan perilaku sesorang misalnya perilaku cuci tangan dipengaruhi oleh beberapa faktor, salah satunya yaitu pengetahuan dan sikap (Notoatmodjo, 2010). Hasil penelitian Anggraini dan Lestari (2019) yang menyatakan terdapat 
hubungan antara pengetahuan dan sikap dengan tindakan cuci tangan pada masyarakat di Kelurahan Pegirian. Jadi semakin meningkat atau baik pengetahuan dan sikap seseorang tentang cuci tangan maka semakin meningkat atau baik juga perilakunya dalam cuci tangan. Pengetahuan merupakan domain yang paling penting dalam merubah perilaku seseorang. Sikap merupakan reaksi seseorang terhadap stimulus yang bersifat tertutup dan mempunyai kecenderungan mempengaruhi untuk melakukan atau tidak suatu tindakan atau perilaku. Upaya dalam peningkatan pengetahuan ini dapat dilakukan dengan cara memberikan edukasi atau penyuluhan kesehatan.

Penelitian lain yang dilakukan oleh Ode (2014) tentang dampak penggunaan media video pada pada pengajaran dan pembelajaran dibeberapa sekolah menengah swasta terpilih di Nigeria menyatakan bahwa penggunaan media video memiliki dampak positif yang signifikan dalam pengajaran dan pembelajaran di sekolah menengah. Pesan yang disampaikan dengan video melibatkan proses visual dan proses audio. Proses visual adalah pesan yang dikodekan oleh pengirim dan diartikan oleh penerima. Kualitas proses pengiriman kode ini ditentukan oleh kemampuan pengirim pesan dalam menyampaikan pesan secara jelas dan logis. Pemahaman pesan dipengaruhi oleh kemampuan untuk memahami pesan yang dikirim. Proses audio adalah proses dimana gelombang suara masuk ke telinga luar dipancarkan ke gendang telinga diubah kedalam getaran mekanik ditelinga tengah dan diubah dibagian telinga dalam menjadi impuls listrik untuk diteruskan ke otak.

Pemberian edukasi tentang cuci tangan pada anak remaja merupakan salah satu bentuk pencegahan dari penyakit Covid-19, dan hal ini juga sebagai bagian dari peningkatan pemahaman dalam menerapkan Perilaku Hidup Bersih dan Sehat (PHBS). PHBS sendiri merupakan salah satu pilar dalam Indonesia Sehat dan strategi dalam mengurangi beban pembiayaan kesehatan bagi masyarakat dan negara. Oleh karena itu PHBS harus diterapkan oleh manusia di setiap sisi kehidupan, dimana saja, dan pada waktu kapanpun (Obelia \& Adliyani, 2015). Salah satunya pada remaja di Rumah Yatim Bina Anak Sholeh, karena dengan hal ini akan membentuk kebiasaan anak, khususnya dalam upaya pencegahan penularan COVID-19 melalui tindakan cuci tangan.

Tangan sebagai media untuk berpindahnya penyakit, karena tangan ini digunakan memegang benda yang tidak kita ketahui kebersihannya secara pasti. Misalnya memegang kendaraan atau handle pintu, yang mana kita tidak tahu ternyata benda tersebut sebelumnya dipegang oleh orang yang batuk atau bersin yang ditutup memakai tangannya sehingga agen penyakit menempel pada benda tersebut. Sehingga akan terjadi perpindahan agen penyakit ke tubuh kita, yang pada akhirnya akan muncul gejala yang sama. Oleh karenanya perlu dilakukan cuci tangan (Kemenkes, 2020).

Cuci tangan yaitu suatu tindakan menggosok tangan dengan sabun secara bersama pada seluruh permukaan kulit tangan dengan kuat dan ringkas, kemudian dibilas dengan air yang mengalir (Potter \& Perry, 2010). Cuci tangan merupakan prosedur atau tindakan dalam membersihkan tangan menggunakan sabun dan air mengalir atau dengan menggunakan cairan berbasis alcohol (hand rub dengan antiseptik)(WHO, 2020). Langkah dalam mencuci tangan menurut Kemenkes (2020) yaitu 1) Basahi tangan, gosok sabun pada telapak tangan kemudian usap dan gosok kedua telapak tangan dengan arah memutar secara lembut; 2) Usap dan gosok punggung tangan secara bergantian dengan lembut; 3) Gosok sel-sela jari tangan dengan bersih; 4) Bersihkan ujung jari secara bergantian dengan posisi saling mengunci; 5) Gosok dan putar ibu jari 
secara bergantian; dan 6) Letakkan ujung jari pada telapak tangan dan gosok secara perlahan dan bergantian.

\section{KESIMPULAN DAN SARAN \\ 1. Kesimpulan}

Pengabdian masyarakat ini dihadiri oleh Pengurus dan Remaja yang berada di Rumah Yatim Bina Anak Sholeh. Seluruh peserta terlibat aktif dalam pelaksanaan edukasi.

\section{Saran}

Pengabdian ini diharapkan mampu meningkatkan pengetahuan tentang pencegahan COVID -19 dan dapat menerapkan perilaku hidup bersih dan sehat dalam kehidupan sehari-hari.

\section{DAFTAR PUSTAKA}

Anggraini, A.O., \& Lestari, W. (2019). Hubungan pengetahuan dan sikap terhadap perilaku cuci tangan pada masyarakat di Kelurahan Pegirian. Jurnal Promkes: The Indonesian Journal of Health Promotion dan Health Education. 7(1): 1-11.

Darmalaksana, W., Hambali, R., Masrur, A., \& Muhlas, M. (2020). Analisis Pembelajaran Online Masa WFH Pandemic Covid-19 sebagai Tantangan Pemimpin Digital Abad 21. Karya Tulis Ilmiah (KTI) Masa Work From Home (WFH) Covid-19 UIN Sunan Gunung Djati Bandung, $1-12$.

Guan, W. J., Ni, Z. Y., Hu, Y., Liang, W. H., Ou, C. Q., He, J. X., ... \& Du, B. (2020). Clinical characteristics of coronavirus disease 2019 in China. New England journal of medicine, 382(18), 1708-1720.

Hardianti \& Asri, W. K. (2017). Keefektifan Penggunaan Media Video Dalam Keterampilan Menulis Karangan Sederhana Bahasa Jerman Siswa Kelas XII IPA SMA Negeri 11 Makassar. Eralingua: Jurnal
Pendidikan Bahasa Asing dan Sastra, Volume 1 Nomer 2, 123-130

Kemendikbud. (2020) 'Perluas Akses Belajar di Masa Covid-19, Mendikbud Luncurkan Program Belajar dari Rumah' Kementerian Pendidikan dan Kebudayaan. [online]. Tersedia di: https://www.kemdikbud.go.id/main/bl og/2020/04/perluas-akses-belajar-dimasa-covid19-mendikbud-luncurkanprogram-belajar-dari-rumah Diakses: 10 Oktober 2020

Kemenkes. (2020).Begini cara mencuci tangan dengan benar. https://covid19.kemkes.go.id/wartainfem/begini-cara-mencuci-tanganyang-benar/\#.X4dDJNAzbIU. Diakses 12 Oktober 2020.

Notoatmodjo, S. (2010). Ilmu perilaku kesehatan. Jakarta: Rineka Cipta.

Obelia, Z., \& Adliyani, N. (2015). Pengaruh perilaku individu terhadap sehat. Majority, Volume 4 (7): 109113.

Ode, E.O. (2014). Impact of audio-visual (Avs) resources on teaching and learning in some selected private secondary schools in makurdi. International Journal of Research in Humanities Arts and Literature, 2(5), 2347-4564.

Potter, P.A., \& Perry, A.G. (2010). Buku ajar: Fundamental keperawatan, konsep, proses dan praktik. Jakarta: EGC.

Rohita, R. (2020). Pengenalan Covid-19 pada Anak Usia Prasekolah: Analisis pada Pelaksanaan Peran Orangtua di Rumah. Jurnal Obsesi: Jurnal Pendidikan Anak Usia Dini, 5(1), 315- 326.

Sanjaya, W. (2012). Media Komunikasi Pembelajaran. Jakarta: Prenadamedia Group.

Sudjana, N\& Rivai, A. (2013). Media Pengajaran. Bandung: Sinar Baru Algensindo. 
Telaumbanua, D. (2020). Urgensi Pembentukan Aturan Terkait Pencegahan Covid-19 Di Indonesia. QALAMUNA: Jurnal Pendidikan, Sosial, dan Agama, 12(01), 59-70.

World Health Organization (WHO). (2020) 'WHO announces COVID-19 outbreak a pandemic' World Health Organzation Regional Office for Europe. [online] Tersedia di: http://www.who.int/en/healthtopics/healthemergencies/coronavirus-covid19/news/news/2020/3/whoannounces-covid-19-outbreak-apandemicDiakses: 10 Oktober 2020

World Health Organization (WHO). (2020). Naming the coronavirus disease (Covid-19) and the virus that causes it. from: https://www.who.int/emergencies/dis eases/novelcoronavirus2019/technical-guidance/naming-thecoronavirusdisease-(covid-2019)-andthe-virus-that-causes-it. Diakses: 12 Oktober 2020.

World Health Organization (WHO). (2020). Clinical management of severe acute respiratory infection when novel coronavirus (nCoV) infection is suspected. Geneva: World Health Organization.

World Health Organization (WHO). (2020). Cuci tangan yang benar menurut Kemenkes dan WHO. https://health.detik.com/beritadetikhealth/d-4903337/cara-cucitangan-yang-benar-menurutkemenkes-dan-who. Diakses: Diakses 17 Oktober 2020. 